\title{
N. W. Thomas and colonial anthropology in British West Africa: Reappraising a cautionary tale
}

\section{Forthcoming in Journal of the Royal Anthropological Institute 22(1), 2016}

\author{
PAUL BASU, School of Oriental and African Studies
}

\begin{abstract}
There is also the question of what a particular anthropologist represents. An era? An entire discipline throughout its history? A particular theoretical moment?
\end{abstract}

(Dureau 2014: 65)

As the first government anthropologist to be appointed by the British Colonial Office, Northcote Whitridge Thomas (1868-1936) (Figure 1) has earned a place in the footnotes of the history of anthropology. Historians of the discipline, including Lackner (1973), Kuklick (1978, 1991), Stocking (1995), Pels (2013) and Kuper (2015), have each, to a greater or lesser extent, discussed his short career in West Africa between the years 1909 and 1915 in the context of their wider explorations of the relationship between anthropology and colonial administration in the first half of the twentieth century. Through their work an orthodox account of Thomas has emerged and been perpetuated: the impression is that he was reckless and eccentric, a dilettante who damaged the reputation of the discipline when it was most concerned to professionalize itself, setting back its adoption as a practical science of value to colonial administration by a generation or more. I argue that this characterization is based on a superficial (mis)reading of the archival evidence that serves a presentist interpretation of disciplinary history - one in which 'the past resolves itself into a simple division between those false ideas that have been refuted and those true ideas that have been subsequently incorporated into contemporary systematic knowledge' (Seidman 1983: 80). Within this progressive narrative, Thomas has come to represent a false turn in anthropological history, a missed opportunity, a 'cautionary tale'.

The issue of presentism in anthropological historiography has already benefitted from considerable scrutiny (e.g. Stocking 1965; Pels \& Salemink 1999). Characteristic of presentist interpretations is an implied continuity between past and present such that 'the problems and doctrines of the present may serve as the criteria for organizing, interpreting, and judging past ideas' (Seidman 1983: 80). The history of the entanglement of anthropology and colonialism is particularly susceptible to such presentist readings, not least in the guise of postcolonial critique. If, however, we are to understand the nature of this entanglement in context, we must, as Pels and Salemink (1999) argue, free the study of colonial anthropology from anachronistic bias and treat it sui generis. Pels and Salemink have also challenged the idea of a singular narrative of the professionalization of academic anthropology, drawing attention to the broader field of ethnographic inquiry and arguing for the coexistence of multiple 'extra-academic' anthropologies, each with its own historical trajectory (1999: 7; see also Pels 2011: 797). In the years prior to the First World War, however, the spheres of academic anthropology, government anthropology and museum anthropology had yet to diverge. Indeed, it was partly through anthropologists' insistence on the value of the discipline in colonial 
administration that anthropology became established as a university subject (Kuklick \& Kohler 1996: 9): Thomas was very much part of that lobby.

A reappraisal of Thomas's career is thus long overdue. Not only does this provide an opportunity to reassess the validity of the orthodox narrative formulated by leading historians of the discipline, but it also affords insight into a particular moment in anthropological history in which the practical value of anthropological knowledge was being debated and could not be taken for granted. Thomas was active at a time when ethnographic research was still perceived as a new and untested field. It was an era of conjecture and experimentation, and the degree to which this period has been obscured in the institutional memory of the discipline is surely an index of the triumph of Malinowski and others in their discursive reinvention of anthropology after the First World War. Indeed, Thomas's career had already been pressed into rhetorical service in the 1920s and 1930s, both by anthropologists keen to define their new scientific methods against earlier paradigms, and by individuals within the colonial administration who gave vent to their prejudices in internal memoranda. I suggest that subsequent historians of anthropology have relied too heavily on these later sources and have failed to interrogate their bias. As such, Thomas has been subjected to a kind of 'double presentism' as the biases of more recent authors have become interfused with those of earlier commentators.

If the story of $\mathrm{N}$. W. Thomas carries a cautionary message, it is a basic lesson about the need to read historical sources critically and in context. The research from which this article is drawn has adopted a more historicist stance and employed a microhistorical approach, involving close engagement with archival records, as well as other traces of Thomas's work in Southern Nigeria and Sierra Leone in the form of the photographs, phonograph recordings, material culture collections, botanical specimens, field notes, and published reports and articles that constitute the legacy of his endeavours (Blench 1995). While this approach may lead to a somewhat localized account of an individual anthropologist's career, it is also consistent with an ethnographic sensibility, which works inductively from small scale investigation to address more general issues. ${ }^{1}$ As Stoler has argued, attending to the minutiae and marginalia of colonial record-keeping allows us to regard archives not only as 'repositories of state power', but also as sites of contestation and uncertainty that reveal the 'restless realignments and readjustments of people and the beliefs to which they were tethered' (2009: 32-33). In relation to wider-reaching debates concerning the relationship between knowledge, power and colonialism, including the emergence of anthropology as a field science and domain of scientific expertise within colonial contexts (e.g. Asad 1973; Cohn 1996; Tilley 2007), the particular case of N. W. Thomas challenges the retrospectively imagined coherence of colonial governmentality and speaks volumes about how tentative and uncertain such projects were in practice (Stoler \& Cooper 1997; Edwards 2014). Thus, as well as lifting Thomas's particular career out of the footnotes of anthropological history, this reappraisal addresses much broader issues relating to the culture of colonial governance, including epistemological uncertainties regarding the use and value of anthropological expertise. As I shall explain, at the time Thomas's employment in West Africa was explicitly regarded as an 'experimental' endeavour by the colonial authorities. Thus, aside from demonstrating how disciplinary pasts are repeatedly reconfigured by 
successive generations in the light of changing contemporary agendas, I argue that it is ultimately this moment of experimentation and uncertainty in the history of anthropology that Thomas represents.

\section{A recognized maniac?}

The significant achievements of Kuklick and Stocking in charting the history of British social anthropology cannot be denied. Their accounts of N. W. Thomas, however, betray a superficial reading of archival sources. This is perhaps forgivable since they were predominantly concerned with documenting broader trends within the development of the discipline rather than engaged in the microhistorical study of particular anthropologists' careers. At the same time, as Goody has noted, their approach has tended to underplay contradictions and disagreements in the record, resulting in 'a measure of distortion of the evidence' (1995: 191). This is certainly apparent in their characterization of Thomas and one might argue that it has been convenient for the purposes of narrative coherence for them to use him as a scapegoat to explain the failure of anthropology to demonstrate its value to colonial administration in Africa at a time when it seemed to have much to offer - particularly in relation to the policy of indirect rule adopted by Sir Frederick Lugard in Northern Nigeria and being implemented throughout British West Africa. In the period in question, prior to his reconciliation with the discipline in the 1920s as the eminence grise of the International African Institute (IAI), Lugard made clear his antagonism toward academic anthropologists, believing political officers in the colonial service were best placed to inquire into matters relating to native law and custom. ${ }^{2}$

Kuklick's and Stocking's accounts generally reflect Lugard's prejudices, but, as will become evident, his views were by no means unanimously held. Indeed, a significant weakness in their analysis is to underestimate the diversity of opinion that pertained within the colonial administration with regard to both anthropology in general and Thomas in particular. From the Secretary of State for the Colonies and ranks of Colonial Office civil servants in Whitehall to the colonial governors, secretaries and district commissioners in the West African territories themselves, colonial authority was not monolithic. On the contrary, there were numerous axes of tension and resistance. Opinions regarding the value of anthropology varied considerably throughout this often dysfunctional bureaucracy, and the failure of the discipline to become more fully integrated into African colonial administration in this early experimental period needs to be reconsidered in a more nuanced manner.

Stocking's discussion of Thomas in After Tylor (1995: 377-8) is drawn largely from Kuklick's account published in The savage within (1991: 199-202). Kuklick, in turn, relies heavily on an internal Colonial Office memorandum and associated correspondence, written in December 1930 and first brought to light by Lackner (1973: 133-6), in which Thomas's career in West Africa was discussed. ${ }^{3}$ This memorandum formed part of the dossier prepared by Colonial Office clerks to inform the Secretary of State for the Colonies' official response to the report of a commission established to investigate the 'disturbances' that had afflicted south-eastern Nigeria in November and December 1929. These large-scale and often violent protests, known as the Aba Riots or 
Women's War, were provoked by rumours of the introduction of a taxation on women that accompanied a census of households in Owerri and Calabar Provinces, and by a more general discontent with the institutions through which British indirect rule was being imposed. Response to the demonstrations was heavy-handed; troops were deployed and over 50 protesters were shot dead (Afigbo 1972).

Evaluating the Aba Commission's report, the Colonial Office determined that the colonial government of Nigeria was itself responsible for provoking the unrest by making administrative decisions that failed to take into consideration local social organization and economic conditions. In a despatch published for Parliament in February 1931, the Secretary of State, Lord Passfield, issued a robust statement to the Governor of Nigeria, arguing that it was 'injudicious and premature to introduce into these Provinces a system of direct taxation without first completing a more intensive study of their social organization'. ${ }^{4}$ Passfield registered his surprise that the colonial administration in Nigeria was not better informed about the local context and he suggested that the Nigerian government would do well to consider 'to what extent the services of investigators trained in anthropological science have been and may still be profitably employed' in gathering such intelligence, thereby avoiding similar errors in the future. ${ }^{5}$

Significantly, Passfield made specific mention of Lugard's attitude to anthropology, and to Thomas in particular: 'It will be remembered that when Sir Frederick Lugard recommended the termination of the appointment of Mr. Northcote Thomas, the anthropologist who was at work in Southern Nigeria from 1909 to 1913, he expressed the view that researches into native law and custom were best conducted by Political Officers'. Passfield then went on to question the value of work undertaken by such administrators, and proposed that steps be taken 'to improve and increase the amount of instruction in anthropology imparted to newly-appointed administrative officers', but concluded that 'it is, in my judgment, hopeless to expect officers who are busily engaged in work of administration to carry out anthropological research of great value'. ${ }^{6}$ Thus, in a direct challenge to Lugard's position, Passfield advocated the employment of professional anthropologists to undertake such work. It is worth noting that around the same time, Malinowski, at the height of his influence as Chair of Social Anthropology at the London School of Economics and adviser to the International African Institute, was also expounding upon the 'practical application' of anthropology in colonial administration, most explicitly in the Institute's journal Africa (Malinowski 1929, 1930). Although Malinowski does not name Thomas, there can be little doubt that Thomas exemplified the kind of outmoded antiquarianism that Malinowski vilified in these and other publications. ${ }^{7}$

Passfield's championing of anthropology in his despatch was informed by the above-mentioned memorandum. This had been prepared by a Colonial Office official named Alexander Fiddian. As a long-serving clerk in the West African Department, Fiddian had been involved in the appointment of Thomas as a government anthropologist in 1908 and he remained a staunch ally of anthropology in the Colonial Office throughout his career. Alongside Fiddian's memorandum, however, is a response by another veteran of the West African Department, J. E. W. Flood, who has been 
described as 'one of the most prejudiced officials in Whitehall' (Wyse 1990: 40). Although Kuklick does follow up some of the earlier Colonial Office correspondence referenced in Fiddian's memorandum, her account relies too heavily on an uncritical reading of the more provocative elements in these two documents. By focusing on the pejorative comments of his detractors, Kuklick has perpetuated a heavily biased opinion of Thomas. While this reading of the archive provides Kuklick with a compelling episode in the saga of the 'colonial exchange' between anthropology and government that she formulates in her analysis, a closer reading of the archive undermines the integrity of this narrative.

Much, for example, has been made of Flood's scornful remarks about Thomas in response to the more balanced evaluation of Fiddian's memorandum:

Mr. Northcote Thomas was a recognised maniac in many ways. He wore sandals, even in [England], lived on vegetables and was generally a rum person. I can quite imagine that the people in Nigeria did not want to have an object like that going about and poking into the private affairs of the native communities, partly because he was calculated to bring a certain amount of discredit upon the white man's prestige, partly because the old residents felt that from the practical point of view they know a good deal about native habits and organisation. ${ }^{8}$

In the margins of Flood's comments, Fiddian adds a characteristically ironic note to the effect that, in the light of the Aba Commission's findings, there seemed to be little evidence that the longserving residents in the colonial administration knew very much about native habits and organization at all. Such marginalia have been ignored, however, and Flood's comments have been taken as being representative of the colonial authorities' view (e.g. Stocking 1995: 377). Having been excavated from the archive, this image of Thomas as a rum, sandal-wearing vegetarian and a 'recognised maniac' has stuck, and, along with other tropes of incompetent eccentricity, has come to define him in the history of anthropology literature. There is no doubt that Thomas could be 'difficult', but as Fiddian remarked in a 1913 minute, so too 'are a good many other learned and clever people - and some others'; a caustic allusion to Lugard himself.'

If the Aba Riots exposed the inadequacies of the political officers' grasp of local social organization in Nigeria, undermining Flood's comments that they knew their territory better than an 'object' like Thomas, Flood's statement that Thomas brought 'discredit upon the white man's prestige' is also deserving of critical reflection. As I shall discuss, at the time of his fieldwork in Southern Nigeria and Sierra Leone, Thomas transgressed vigilantly-maintained cultural boundaries between colonizer and colonized in a way that disturbed the colonial order and offended members of the colonial administration (Stoler \& Cooper 1997). In surviving correspondence from Thomas, there is, for example, no hint of the ingrained racism one finds in Malinowski's diaries from the same period (Malinowski 1967); nor is there any tendency to paternalism or idealization of native peoples. Rather, Thomas seems to have respected his informants as intelligent, flawed, rational and selfinterested individuals, neither inferior or superior to himself. The impression is of an industrious fieldworker, seemingly unburdened by the racial prejudices that characterized the colonial milieu of 
the era. On the contrary, his invective was generally reserved for the absurdities of his own society and its self-regard. No attempt has been made, however, to read Flood's vituperative remarks 'against the grain' or consider that Thomas's ability to unsettle colonialist sensibilities may be regarded as an achievement for anthropology.

Before considering his career in more detail, it is worth summarizing some of the characteristics that have come to define Thomas in what I refer to as the orthodox account that has emerged through the work of Kuklick (1991) and been reproduced by Stocking (1995) and others. Thus, there is the suggestion that Thomas was a charlatan who 'managed to convince the civil servants in the Colonial Office to employ him' (van den Bersselaar 1998: 176; 2004: 75); that he was disingenuous in his use of the 'offices of the [Royal Anthropological Institute] to find himself an advisory committee of distinguished scholars' (Kuklick 1991: 199); that it 'was put on official notice ... that "purely scientific research ... must not interfere with his main work"” (Kuklick 1991: 199); that 'he spent much of his time conducting the very sort of impractical research that he was instructed not to do - in particular, analysing linguistic data' (Kuklick 1991: 200); that he 'was clearly eccentric. A man who proposed to "ingratiate [him] self with [his] subjects" by donning false teeth filed in African fashion' (Kuklick 1991: 200-1); that he was 'dismissed' or 'fired' from Nigeria and sent to Sierra Leone to make an investigation of the purportedly cannibalistic Human Leopard Society (Kuklick 1991: 201; Pels 2011: 801); that he wrote a report on the Human Leopard Society but 'refused to divulge the identities of the murderers he had interviewed, arguing that the anthropologist's code of professional ethics required him to maintain the confidentiality of the relationship he had with his informants' (Kuklick 1991: 201; see also Stocking 1995: 378; Pels 2011: 801); that he 'violated the conditions of his employment, using time that ought to have been spent on official business to pursue his linguistic research' (Kuklick 1991: 201); that 'after one tour of duty in Sierra Leone, he was sent home, his dismissal charitably euphemized as part of the general wartime retrenchment' (Kuklick 1991: 201; see also Stocking 1995: 378); and that he was 'diverted by the esoteric, impractical aspects of anthropological research' (Kuklick 1991: 202).

The narrative that emerges in this orthodoxy is that it was Thomas's reckless lack of professionalism, coupled with fundamental character flaws, that tarnished the reputation of anthropology in the eyes of the colonial administration - in short, that Thomas was a poor ambassador for the discipline, fulfilling the worst expectations of the 'practical men' who administered Britain's empire. Kuklick sums up her analysis stating that,

The history of Thomas's colonial appointment served as a cautionary tale in official circles for decades after his removal from the services of Sierra Leone. His case proved to colonial officials that the practical man could not employ the professional anthropologist for routine administrative purposes. (Kuklick 1991: 201)

This analysis is reiterated by Stocking, though with a further gloss arguing that Thomas lacked the gentlemanly breeding that might have commanded respect 'in the clubby atmosphere of colonial bureaucracy' (1995: 378). Others, too, have invoked Kuklick's narrative, noting, for example, 'how 
[Thomas's] behaviour and the type of works he produced served as a deterrent to any temptations the Colonial Office might have of hiring another professional anthropologist' (van den Bersselaar 1998: 177; see also van den Bersselaar 2004: 76; Mills 2008: 51; Lewis 2014: 89). While there is undoubtedly some truth to these assertions, they do not tell the whole story. In some cases there are outright factual inaccuracies; in others, inferences are imputed through choices in vocabulary that are simply not sustained in the historical record.

\section{A man of great industry, likely to render good service both to the government and to science?}

Thomas was born in the English market town of Oswestry in Shropshire, close to the Welsh border, where his family were prominent members of the Congregationalist chapel movement. His father is recorded as being a draper and borough finance clerk. At around the age of 10, Thomas was informally adopted by his maternal aunt and her husband, a local newspaper proprietor named John Askew Roberts, and he moved into their comfortable villa, Croeswylan. Roberts was an amateur antiquarian and folklorist, who wrote a regular column entitled 'By-gones' in the Oswestry Advertizer, which Thomas would later use as a source for his own studies of Cambrian folklore. Thomas's aunt and uncle had no children of their own, and they took charge of Thomas's education at Oswestry Grammar School. In 1884, when Thomas was 16, his aunt and uncle died within weeks of one another, leaving Croeswylan to him in their will along with the sum of $£ 200$. It is likely that the house provided Thomas with an income, funding his studies at Cambridge.

Thomas was admitted to Trinity College in 1887. Initially a student of Classics, he later switched to History, graduating with a BA in 1890 and an MA in 1894. The degree to which he was acquainted with J. G. Frazer at Trinity is unclear, but it was while studying at Cambridge that Thomas decided to pursue a career in folklore. In the dedication to his 1906 monograph, Kinship organisations and group marriage in Australia, it is Charlotte Burne whom he acknowledges as 'first guid[ing] my steps into the paths of anthropology' (1906: v). Like Thomas, Burne was a native of Shropshire, where she was also an energetic field collector of folklore, publishing the three-volume Shropshire folklore between 1883 and 1886. Burne became the first female president of the Folklore Society in 1909, the year that Thomas embarked on his initial anthropological tour in Nigeria. As Stocking notes, prior to the First World War, anthropologists with sociological interests were more likely to be active within the Folklore Society than the (Royal) ${ }^{10}$ Anthropological Institute (1995: 371). This is certainly reflected in the membership of the governing bodies of these institutions. In 1907, when Thomas was serving on both, his colleagues on the Council of the Folklore Society included Haddon, Marett, Myers, Rivers, Seligmann and Westermarck - names that we would readily identify as founding figures in British social anthropology. ${ }^{11}$

When Thomas left Cambridge in 1894, anthropology had yet to be established in British universities and it is a sign of his cosmopolitan frame of mind and his commitment to equipping himself with as robust an anthropological education as possible that he enrolled at the École Pratique des Hautes-Études in Paris, where he studied 'primitive religion' under Léon Marillier. Among Thomas's contemporaries in the so-called 'Fifth section' at the École Pratique were Marcel Mauss and Arnold van Gennep. Remarking that it was 'a disgrace that an Empire like Great Britain 
has no School of Anthropology', Thomas wrote a short article about the École Pratique in Folklore, believing that it should be better known in British anthropological circles (Thomas 1896).

Candidates at the École were required to complete two years of supervised study successfully before qualifying to write a thesis, which had to be submitted within the following two years. Thomas combined his knowledge of Welsh folklore with his learning in anthropological theory and submitted a thesis entitled 'La survivance du culte des animaux au Pays de Galles' in 1897, which was subsequently published (under a slightly modified title) in the Revue de l'Histoire des Religions (Thomas 1898). He was duly awarded a Diplôme de l'École des Hautes-Études and became a corresponding member of the Société d'Anthropologie de Paris.

After his studies in Paris, Thomas pursued his interests in Volkskunde and Völkerkunde in Germany, where he was based in Kiel. Here, it appears that his research continued to focus on folk superstitions concerning animals, which, following Tylor's (1871) 'doctrine of survivals', he hypothesized, provided evidence for the former existence of totemism in Europe. Thomas was an adept multilinguist and was able to draw upon a wide range of English, French, German and Scandinavian sources in this comparative project. In 1900 Thomas returned to Britain and was engaged as assistant secretary and librarian at the Anthropological Institute, becoming a Fellow in 1904. The years leading up to his departure for Southern Nigeria in January 1909 were intensely busy and hugely productive for Thomas, and saw him established at the very centre of British anthropological networks. Between 1900 and 1909, Thomas published well over 50 articles in academic journals and wrote, edited or co-edited more than 10 books (Alexander 1995), including the above mentioned synoptic study of Aboriginal kinship systems in Australia - a significant departure from his earlier work on animal superstitions in Europe and, of course, de rigueur at the time (Langham 1981). He was also editor of popular book series including County folklore and Native races of the British empire, and, as previously noted, served on the Councils of both the Folklore Society and Royal Anthropological Institute.

Indicative of his growing stature within anthropological circles, Thomas served alongside Rivers and Marett on the editorial committee of a festschrift to honour E. B. Tylor's 75th birthday. As Rivers and Marett acknowledge (1907), 'the actual work of editing the volume and seeing it through the press [lay] almost entirely in the able hands of Mr. Thomas'. In many respects, the contents page of the festschrift can be read as a roll-call of the leading figures of pre-functionalist British anthropology, including Balfour, Frazer, Haddon, Lang, Marett, Myers, Read, Rivers, Seligmann, Westermarck, and, of course, Thomas himself, whose contribution debated theories concerning the origin of exogamy. Contrary to the orthodox view, Thomas was no charlatan or dilettante who wheedled himself into favour with the Royal Anthropological Institute or Colonial Office. While he lacked the reputation of Haddon or Rivers, he was part of the circle, highly qualified, and an active participant in the anthropological debates of his generation. Indeed, it was Tylor himself who recommended Thomas to the Colonial Office in 1908 when he was approached for advice about editing the responses to a Notes and queries style questionnaire that had been distributed to district officers throughout British West Africa. ${ }^{12}$ 


\section{Native law and custom in West Africa}

The potential value of anthropological knowledge in colonial governance had already been recognized in the Indian Civil Service, giving rise to the Ethnographic Survey of Bengal (1885-91) and Ethnographic Survey of India (1901-09) under the supervision of Sir Herbert Hope Risley (Kuklick 1991: 194-99; Urry 1993: 102-19). In contrast to the adoption of Indian forest conservation policies in Africa (Barton 2002), and despite repeated calls to establish an overarching Imperial Bureau of Anthropology (e.g. Anon 1909), there seems to have been no attempt to transfer Indian ethnographic survey practices to Britain's African territories. Rather, the sequence of events that led to the employment of Thomas in West Africa began with a proposal, sent by A. D. Russell, Chief Magistrate of the Gambia, to the Colonial Office in 1905, outlining a method for collecting information about the 'customary laws' of the native populations of British West Africa. Such intelligence, Russell argued, would be useful not only for members of colonial judiciaries, but also for district commissioners 'in guiding and advising [native] tribunals, and to the people themselves in giving certainty to decisions, and inspiring confidence as to the correct application of their laws'. ${ }^{13}$ Russell enclosed a thirteen-page questionnaire that he had drafted which could be distributed to district commissioners and legal officers to guide their collection of this information.

Russell's proposal was enthusiastically adopted by the Colonial Office, and quantities of the questionnaire were distributed to each of Britain's West African dependencies in March 1906. In a covering letter, Lord Elgin, the serving Secretary of State for the Colonies, reiterated the value of compiling and publishing 'a trustworthy and systematic account of the law and customs of the various native communities in British West Africa':

Such a compilation should enable the administration of justice to be conducted with greater certainty in all matters involving a knowledge of native customary law, and should facilitate the keeping of the measures and the policy of the Government regarding native affairs in accordance with the traditions and feelings of the natives, so far as that is desirable. ${ }^{14}$

Elgin further suggested that the work of compiling materials would best be undertaken by government officers, 'whose experience has fitted them for the task' ${ }^{15}$

While the legal focus of Russell's questionnaire seemed to be of practical utility in colonial governance, the limitations of this approach were recognized by some. Sir Walter Egerton, the Governor of Southern Nigeria, for example, forwarded correspondence from his Assistant Conservator of Forests, R. E. Dennett, and supported his opinion that it might be better to replace Russell's questionnaire with one that had recently been prepared by the Anthropological Institute for use in Africa and, indeed, that it would be advantageous to employ an anthropologist to collect the information. ${ }^{16}$ Dennett was not only a forester, he was also an accomplished amateur anthropologist and collector who had spent many years trading in the Congo prior to his appointment in Southern Nigeria in 1902. Dennett had evidently been sent Russell's questionnaire and, being based in Benin City, had compiled information on Bini law and custom. He was frank about its shortcomings: 'If the Government could only see its way to appoint a trained 
anthropologist say for five years to do this work it would be far better done'. ${ }^{17}$ It is possible that Dennett's suggestion emerged from discussions with Thomas. Thomas had recently worked with Dennett, editing the manuscript of his book, At the back of the black man's mind (1906), which included a comparative study of Vili and Bini customs and belief. Egerton was evidently persuaded by Dennett's suggestion and offered to find $£ 500$ from the Southern Nigeria budget to employ an anthropologist. The Colonial Office, however, were not convinced by the plan. They insisted on the legal purpose of the initiative, and, as Reginald Antrobus, the Assistant Under Secretary with responsibility for the West Africa Department, wrote: 'A single person, however high his scientific attainments might be, cannot possibly accumulate materials as extensive or as valuable as those which the whole body of district officers can gather together'. ${ }^{18}$

Over the following two years, the reports on native law and custom prepared by various officers from throughout British West Africa trickled into the Colonial Office and the issue now became how best to publish them. The view was taken that it would be best to print them more or less in their entirety in a single volume, and that a retired judge who had served in West Africa might be approached to edit the volume. On this occasion, it was Sir William Wallace, Acting High Commissioner for Northern Nigeria, who put forward an alternative proposal, suggesting that a single volume would be impractical and that it would be better to produce separate volumes for each of the colonies, which could be updated as new information became available. More significantly, Wallace expressed concern that customary practices could not be regarded as 'laws', and that, rather than providing guidelines for making legal decisions, the information gathered had a broader value, enabling political officers to 'have an intelligent and sympathetic understanding of the people with whom they have to deal'. With these more general objectives in mind, he proposed that it would be better for an anthropologist to be entrusted with the editorial work and not a lawyer. ${ }^{19}$ Evidently no longer persuaded of the judicial value of the exercise, the clerks of the West African Department, including Alexander Fiddian, were sympathetic to Wallace's proposal and it was suggested that they might approach Tylor, still the best-known anthropological authority, for advice. In June 1908, a letter was sent to Tylor, enclosing samples of the reports and asking if he could recommend a suitably qualified person to undertake the editorial work. Perhaps mindful of the fine work done on his own festschrift, Tylor put forward Thomas's name for the job, stating that he was competent to deal with the reports 'both on the administrative and anthropological sides' ${ }^{20}$

The Colonial Office duly sent copies of the reports to Thomas, along with a précis of the various discussions to date and an invitation to call at the Colonial Office once he had had an opportunity to examine the material. ${ }^{21}$ Thomas provided a detailed, but also highly critical, evaluation of the reports, arguing that they were quite unequal in value, owing partly to faults in the questionnaire that had been distributed and partly to the inexpert manner in which the data had been gathered. The gathering of reliable information on 'the more elusive side of social organisation', he argued, was better entrusted to an expert 'familiar with modern anthropological methods', rather than to busy district officers untrained in ethnographic data gathering techniques. He advised, therefore, against publishing the reports and suggested instead that they be used as the basis for more extensive anthropological survey work. ${ }^{22}$ Fiddian notes that, in the meeting at the Colonial Office, Thomas 
was strongly in favour of Egerton's earlier suggestion, summarized in the papers given to Thomas, to appoint a trained anthropologist to work in West Africa, and he let it be known that, if required, he would be prepared to undertake this work himself. ${ }^{23}$

The Colonial Office's confidence in the value of the reports and the abilities of political officers to collect ethnographic information was seriously shaken by Thomas's criticisms. As Fiddian notes, 'the expert we asked in to bless has cursed', and it was felt that it would be impossible to publish the material already collected: 'the risks of incurring accusations of inaccuracy and ignorance are too great'. ${ }^{24}$ Whilst acknowledging that it was a significant departure from what was originally contemplated, it was agreed that Thomas's proposal deserved serious consideration. Fiddian proposed that Thomas be asked to provide a summary of his credentials and Tylor was again approached for his views on the matter. Thomas thus provided a summary of his qualifications and experience, while letters of support were sent by a triumvirate of anthropological authorities: Tylor, Frazer and Read (none of whom, of course, had any experience of fieldwork or of West Africa). Frazer wrote that,

I have been acquainted with Mr. Thomas for a good many years, and I know him to possess a wide knowledge of ethnology and to be animated by a keen enthusiasm for the study. He is a man of great industry, as his many publications suffice to prove. If he were appointed Government Ethnologist to West Africa, I believe that he would be likely to render good service both to the Government and to science. ${ }^{25}$

It is worth noting that, in outlining his experience, Thomas claimed to have been 'devoting especial attention to West African subjects' over the past year or more and referred to a recently published article he had written on African markets (Thomas 1908). Along with his editorial work on Dennett's book, this article marked a significant departure from his work on European animal superstitions and Australian kinship, and suggests that he had indeed turned his attention to Africa prior to his encounter with the Colonial Office.

Needless to say, the impression of Thomas as an accomplished and industrious scholar, as described by Frazer, is at variance with that evoked by historians of anthropology. Thomas certainly seized upon the opportunity to advocate for the value of anthropology when invited to do so by the Colonial Office, but to imply that he merely connived to create a position for himself would be incorrect. A glance through the district commissioners' reports, the majority of which were deposited at the Royal Anthropological Institute, leaves one in no doubt as to the sagacity of Thomas's opinion. ${ }^{26}$

\section{An investigation of an experimental character}

While the Colonial Office perused Thomas's résumé and references, a telegram was sent to Egerton in Southern Nigeria, enquiring whether he would still be prepared to support the appointment of an anthropologist. ${ }^{27}$ Egerton replied in the affirmative, noting that provision would be made for this in his financial estimates for $1909 .{ }^{28}$ The suggestion to focus work initially in Southern Nigeria's 
Central Province came from Thomas, and is likely to have been influenced by his familiarity with Bini laws and customs through his editorial work on Dennett's book rather than any more pressing political issues in the region. Thomas was also acquainted with Dennett's senior colleague, the Conservator of Forests, H. N. Thompson, who was also ordinarily based in Benin City. The companionship of Dennett and Thompson would therefore ease Thomas's entry into what were, for him, the unknown worlds of both West Africa and the Colonial Service. Indeed, when his appointment was confirmed, Thomas requested that his departure for Southern Nigeria might be delayed until January 1909, so that he might travel out with Thompson, whose leave in England was then due to end. ${ }^{29}$

The orthodox account of Thomas's employment infers that he held a more permanent position that was terminated prematurely owing to his insubordination. In fact, Thomas was only ever employed on a temporary, tour by tour basis. Under this arrangement, he undertook three successive tours in Southern Nigeria (January 1909-April 1910; November 1910- December 1911; July 1912-August 1913), and one tour in Sierra Leone (February 1914- April 1915) (see Thomas 1910; 1913-14; 1916). While a more permanent appointment was initially not ruled out, Fiddian made it clear that this would be unlikely, entailing lengthy negotiations with the Treasury as well as the colonial governments in West Africa. In the first instance, then, it was agreed that Thomas would carry out 'an investigation of an experimental character into native law, custom, \&c.' in Southern Nigeria. ${ }^{30}$ Although, in the event, Thomas spent fifteen months in the field during this first tour, it was originally intended to last only twelve months, followed by two months' leave on full pay. Thomas's salary would be $£ 750$ per annum, plus provision of a tent, camp outfit and travel expenses, including first class passage to and from the colony. It was agreed that on completion of the tour, he would submit an account of the work undertaken, which would be reviewed by a committee of leading anthropologists, and a decision then taken whether to extend the arrangement to include, for example, tours in other West African dependencies. ${ }^{31}$

The salary was generous and, indeed, in excess of that paid to a senior district commissioner. With the additional costs of publishing Thomas's reports, mounting his photographs in albums, duplicating his phonograph recordings, and covering his equipment and travel expenses, the anthropological survey represented a significant annual expenditure ( $£ 1,210$ was set against Thomas's 1912-13 tour, for example). ${ }^{32}$ It is important to note that this financial burden was placed on the host colony itself, and was not paid directly by the Colonial Office. This is a significant factor in understanding the tensions that later emerged in the three-way relationship between Thomas, the Colonial Office, and the individual colonies in which he worked and which were burdened with paying for his investigations. Kuklick stresses the ideological grounds for what she characterizes as Thomas's 'dismissal' from the West African service, but the constant gripe of colonial governors was a perceived imbalance between cost and benefit. There was a sense that Thomas's work might be of value in the long term, but, at times of financial stringency, in which colonial governments were under constant pressure to reduce expenditure, it was felt that the short term practical benefits to colonial governance were not sufficient to warrant the expense. At an early stage, the Colonial Office had discussed distributing the cost across all of the West African 
territories, but this was not pursued. ${ }^{33}$ It seems likely, however, that if the Colonial Office had devised an alternative method of funding Thomas's work, the saga of early colonial anthropology in British West Africa would have been rather different. It could be argued that it was not until the 1940s, with the establishment of the Colonial Social Science Research Council that such an alternative was found (Mills 2008: 69-91).

Now that the anthropological survey in Southern Nigeria had been given the go ahead, Thomas was asked to submit schemes of work to be done in his initial 'experimental tour' and to put a plan together for further tours should the experiment continue. Conscious perhaps of his lack of fieldwork experience, Thomas proposed that he seek the advice of more senior colleagues before submitting these schemes. Thus, in October 1908, he consulted individually and then as a committee Balfour, Haddon, Read, Ridgeway and Seligmann. In a letter reporting on the process, Thomas noted that Haddon and Seligmann 'had great experience of field work', and that Seligmann was soon to undertake 'an ethnographic survey of the Egyptian Soudan' and Haddon was planning similar work in Uganda. ${ }^{34}$ In presenting his scheme of work, Thomas stressed that, 'without actual experience of the area', his proposals must necessarily be tentative. Consistent with the concept of 'intensive study' developed by Haddon, Rivers and Seligmann, Thomas argued that it was 'of more importance to deal with a small area thoroughly than to cover a wide area in a less complete manner', and to these ends he reiterated his proposal that his first tour concentrate on investigating the laws and customs of the Bini- or Edo-speaking peoples of the Central Province. ${ }^{35}$

In the scheme of work for his first tour, Thomas proposed basing himself initially in Benin City before moving out into more rural districts. As well as eliciting information from the native peoples themselves, he made a point of demonstrating how he would liaise with local political officers:

I shall consult the records of the District Commissioners' courts \& take the opportunity of calling their attention to points which they can investigate further \& to the methods by which information can most readily be gathered. By taking the replies to the questionnaires sent in from each district it will be possible to give to the officers concerned a more effective insight into native ideas than they could gain from perusal of any written commentary. ${ }^{36}$

He stressed the importance of linguistic investigation and the need for a standard scheme of transliteration, such as that used by the Royal Geographical Society. He outlined his proposed method of assembling word and phrase lists in each of the various languages of the region, and how he would supplement written annotation by using phonograph recordings. To these ends he emphasized the need for reliable local interpreters. He proposed to complement the information already gathered by district commissioners on matters of agriculture and food with an investigation into 'other branches of native technology', but suggested that it would 'not be desirable to include in the scheme anthropometric measurements \& other research of a less practical nature'. Finally, Thomas suggested that 'it seems desirable for my investigation to be as far as possible unofficial, in order to avoid ... reticence \& suspicion on the part of native informants'. ${ }^{37}$ While he recognized that being too closely identified with the government would skew the results of his investigation, he 
was perhaps naïve to think that he could effect such a distancing. All the same, this provided him with a rationale to keep at arm's length from the colonial administration when it suited him. With regard to the request that he provide a prospective outline of future research, Thomas explained that the development of a workable scheme would need to wait until he had gathered further information about the local context.

Thomas's scheme of work for his first tour was approved at the Colonial Office. Given the involvement of Haddon, Seligmann and others in Thomas's 'committee', Fiddian felt they were justified in saying that the plans 'have the sanction of high anthropological authority' and minuted that he had no criticisms. Again, contra Kuklick, it is important to note that no objections were raised regarding Thomas's proposals to engage in linguistic analysis, and it was felt that work that had a 'more strictly scientific' purpose could be accommodated insofar as it did not 'encroach materially on the more "practical" side of the enquiry'. ${ }^{38}$ A despatch was thus sent to Egerton enclosing Thomas's scheme of work, in which Antrobus impressed the importance of supporting the initiative:

I have no doubt that your officers will realise the importance and value of the work on which Mr. Thomas is to be employed, and will gladly give him all the assistance in their power. I may say that I take special interest in this investigation - an interest which I have no doubt is shared by you as it is by many eminent men of science in this country. Mr. Thomas is of course a stranger to West Africa, and the success of his tour and the prospects of continuing \& extending the investigation must depend largely on the help which he can obtain from those who possess local experience \& authority. ${ }^{39}$

\section{Misreading the archive}

A fuller discussion of the methods used and materials gathered during Thomas's anthropological tours in Southern Nigeria and Sierra Leone will be the subject of a future article. Here I concentrate on the main criticisms of Thomas articulated in Kuklick's and Stocking's influential disciplinary histories. As I have argued, these accounts have identified Thomas's failings with allegations of incompetence and insubordination, epitomized in his insistence of pursuing linguistic research, his displays of eccentricity (such as donning false filed teeth to 'ingratiate' himself with informants), and his lack of cooperation with regard to an investigation into the Human Leopard Society in Sierra Leone. These are key narratives in the saga of Northcote Thomas and the history of British colonial anthropology, but are based, I argue, on a misreading of the archive. While this orthodoxy has dominated since the early 1970s, as I have mentioned, Thomas's work was also dismissed by earlier generations of anthropologists too, representing an era of amateurism and antiquarianism. I suggest, however, that the style of research pursued by Thomas in West Africa was exemplary for its day. This was a time of transition and experimentation that saw a departure from the itinerant survey work employed by government anthropologists in India and the deployment of more intensive approaches developed by veterans of the 1898 Torres Strait Expedition in which the individual fieldworker 'studies every feature of life and custom in concrete detail and by means of vernacular language' (Rivers 1913: 6): a method that would come of age in Malinowski's fieldwork 
in the Trobriand Islands in 1915-16 and 1917-18. While Thomas's fieldwork represents a methodological bridge between survey and intensive approaches, he was not especially innovative; rather he practiced anthropology 'by the book', assiduously following the guidelines laid out in the 1899 edition of Notes and queries on anthropology. Indeed, there is little evidence to suggest that Thomas's fieldwork practices changed significantly over the six intense years in which he spent either on tour in West Africa or preparing his reports (Figure 2). What is striking is the sheer energy of his endeavours. He thrived on the rigours of research in West Africa and often mentioned in correspondence his sense of physical wellbeing in the field. As Fiddian's Colonial Office colleague, Charles Strachey, would minute in 1913: 'A more energetic man - impervious to the hardships of bush life \& disease - can hardly exist. He gets on well with natives, \& his appetite for work (even when on leave) is only equalled by that of Sir F. Lugard' ${ }^{40}$

In relation to the apocryphal failures of Thomas mentioned above, I have already noted that the colonial authorities initially approved his proposals for conducting linguistic research, and there is ample evidence in subsequent correspondence that the work of compiling word lists, dictionaries and grammars, as well as establishing standard orthographies of native languages, was considered to be important. The matter of Thomas's supposed predilection for wearing filed false teeth is based on a careless misreading of the archival evidence. Prior to his departure for Southern Nigeria in 1909, Thomas maintained close contact with the Colonial Office as he assembled his kit and refined his plans. In a letter to Fiddian, he enclosed a list of equipment to be included in his 'Anthropological Outfit' that he had compiled with the aid of his committee of senior anthropological advisers. The outfit includes photographic equipment, phonograph recorders, an anthropometric kit, typewriter, prismatic compass, field glasses, notebooks, and so forth. In an aside at the end of his letter, Thomas adds,

A friend in the anthropological line suggests that while about it I may as well have a few sets of teeth with the front ones filed after the fashion of the tribes I am to visit. I don't know what these are but if you think it desirable for me to ingratiate myself with my subjects by all means in my power I will ascertain. Meanwhile I do not put half a dozen sets of teeth among my anthropological requirements. ${ }^{41}$

In an accompanying minute, Fiddian evidently takes this seriously and suggests that they ask Thomas if he thinks the filed teeth would be 'a material help'. This was duly followed up by Strachey, who reported back that Thomas had made mention of the teeth in jest and that 'he did not want his remarks to be taken seriously'. ${ }^{42}$ The matter of the false teeth, then, speaks not of Thomas's folly, but of an ironic sense of humour that is sometimes evident in his correspondence, though not always appreciated.

A similar error is made with regard to Thomas's work in Sierra Leone. At least since the 1850s, parts of what would become the Sierra Leone Protectorate had been troubled with sporadic outbreaks of apparently ritualistic murders perpetrated by the so-called Human Leopard Society (Beatty 1915; MacCormack 1983). As a counter measure, the Human Leopard Society and related 
cults were outlawed in a series of proclamations and ordinances, culminating in the establishment, in 1912, of a Special Commission Court to investigate the matter and try those suspected of being involved in these illegal practices. Punishment of those found guilty of participation in unlawful societies was severe; many were convicted of murder and executed. Throughout this period, the colonial administration in Sierra Leone struggled to understand the operation of indigenous institutions, including both lawful and unlawful 'secret societies' and their 'medicines', as well as their political function in society. Thus, Sir Leslie Probyn, Governor of Sierra Leone between 1904 and 1910, had been particularly receptive to the Colonial Office's request that native customs and laws be investigated when Russell's questionnaire was distributed in 1906. When the opportunity later arose to comment on the results of Thomas's first tour in Southern Nigeria, Probyn responded enthusiastically, but he also drew attention to the difficulty of distinguishing those areas of research of direct practical relevance to colonial administration from what Kuklick describes as 'the esoteric, impractical aspects of anthropological research' (1991: 202). 'Enquiry into the powers of the Magicians', as Probyn termed the leaders of the Poro and other sodalities, was an important area of investigation, not least since 'the Magician is a factor which Administrators are compelled to take into consideration. ... [T] heir powers affect the family and political life of the whole people'. ${ }^{43}$ What Probyn had the wisdom to recognize was the inseparability of politics, law, religion, witchcraft and magic in West African society.

Unfortunately, by the time Lugard's antagonism toward Thomas led to the proposal, in November 1913, that his fourth tour take place in Sierra Leone, Probyn had left West Africa for the Caribbean. In a despatch to his successor, Sir Ernest Merewether, however, Probyn's petition was not forgotten and it was suggested 'that among other matters [Thomas] might pay attention to the practices of the "Magicians" and of the Leopard and other secret Societies'. ${ }^{44}$ Merewether and his Executive Council agreed to fund the proposed tour, and, in a subsequent letter to the Colonial Office, Thomas reported that he had had an interview with Merewether, who was in England on leave, to discuss the arrangements. Thomas states that 'His Excellency ... proposes that I should go in the first instance to the Mendi country, and thinks it desirable that I should devote a good deal of attention to the language as the best method of going into the question of the ritual murders' ${ }^{45}$ In the meanwhile, the activities of the Special Commission Court had wound down and the Colonial Office had received reports from both its chief judge, Sir William Brandforth Griffith, and Kenneth Beatty, a police magistrate in Sierra Leone who had been attached to the Court, concerning the Human Leopard trials. ${ }^{46}$

While the issue of ritual murders and secret societies was certainly in mind when Thomas's tour in Sierra Leone was being considered, it would be wrong to state that he was sent to Sierra Leone specifically to make an investigation of the Human Leopard Society. Indeed, Kuklick's comments about the report that Thomas supposedly later submitted on the Society - including the statement that he 'refused to divulge the identities of the murderers he had interviewed, arguing that the anthropologist's code of professional ethics required him to maintain the confidentiality of the relationship he had with his informants' (1991: 201) - are puzzling to say the least. There is no reference to such a report, or to Thomas's appeals to professional ethics, in the Colonial Office files 
that Kuklick cites as her source for this information. In fact, it is quite clear from other correspondence in the Colonial Office archive that Thomas did not write a report on the Human Leopard Society at all. Indeed, a more careful reading of the archival sources shows that he made no attempt to investigate the issue. As he states in a letter accompanying the manuscript of his more general report:

I obtained no information as to the Human Leopard Society, owing to the fact that, in the regulations laid down for my guidance, it was set forth that I was to hand over to justice any one whom I discovered to be connected with the Society. I am of the opinion that suitable informants are not likely to come forward if it is laid down that they are to be rewarded by being hanged from the neck till they are dead. ${ }^{47}$

Here again we see evidence of Thomas's caustic humour, but also a very pragmatic explanation for why he failed to pursue this area of research.

Thomas did attempt to research lawful secret societies and made arrangements to be initiated into the Poro society in Yonibana. In this case, however, his investigations were frustrated by the interventions of an assistant district commissioner, W. R. Lyons, as Thomas explains in response to a review of his published report by Ray:

I should have been initiated into the Poro Society ... but for the zeal, I hope well meaning, of a youthful official, who obliged with his advice puisne judges, members of the Legislative Council, and anyone else who their sins brought across his path. On the eve of my initiation he telegraphed the chief, with whom I had carried on negotiations for many a month, forbidding him to let me go near Poro, Bundu, or any other sacred bush. (Thomas 1917: 1734)

The district commissioner later argued that his assistant acted to protect the interests of the local population, but, at the time, we must acknowledge that the idea of a white employee of the colonial administration entering such a cult transgressed what was perceived as a fundamental boundary distinguishing the civilized European from the primitive African, and it was precisely this kind of behaviour - akin to 'going native' - that was likely to bring 'discredit on the white man's prestige'. ${ }^{48}$

The lack of cooperation shown by the Sierra Leonean administrators elicited expressions of exasperation from the Colonial Office under-secretaries and clerks and further exposes the tensions between central government in London and the colonial administrations in West Africa, which, more than any other factor, led to the failure of this anthropological experiment. These tensions are plainly evident in Fiddian's comments on the issue:

It would be incredible that a Colonial Government could have behaved so stupidly, if experience in this Department had not taught one that there was nothing so stupid that some 
Colonial Government would not do it! We actually sent to the Governor in a numbered despatch the suggestion that Mr. Thomas should 'pay attention to the practices ... of the Leopard and other secret societies' \& they might at least have referred to us before stopping his investigations in this wooden-headed way. A priceless opportunity of finding out what really lies behind \& underneath these murders and mysterious associations has been deliberately wrecked by the very people whom it most concerned to know it. ${ }^{49}$

The inscrutability of institutions such as the Poro society remained a matter of anxiety for subsequent colonial governments in Sierra Leone, eventually resulting in a Colonial Office investigation into the issue in the 1950s, to which the anthropologist Kenneth Little contributed a substantial report. ${ }^{50}$

\section{A failed experiment?}

As previously noted, a more thorough discussion of Thomas's anthropological surveys in West Africa, including his use of photography and phonograph recordings, and his material culture and language collecting practices, will be the subject of a future article. My concern here has been to employ a microhistorical approach to reassemble the context of this early experiment in colonial anthropology from the archival evidence, and thus to challenge the 'double-presentist' bias evident in the orthodox account that has emerged through the work of Kuklick and Stocking. Such an approach shows that Thomas was not a peripheral figure, but an energetic participant in the anthropological networks and debates of his time. He was among those who lobbied for the creation of an Imperial Bureau of Ethnography, and, like many of his generation, he believed strongly in the value of anthropology as an instrument in colonial governance. His appointment as government anthropologist provided an opportunity to put these ideas into practice, and his practice was informed by the advice of experienced fieldworkers such as Haddon and Seligmann as well as Notes and queries on anthropology - the authoritative research methods handbook of the day.

And yet there is no denying the fact that the Colonial Office's early experimentation with anthropology in West Africa was perceived as a failure. Of course 'failure' is an important part of the experimental process; the crucial thing, however, is to analyse the causes of failure such that the appropriate lessons are learnt. At the time, influenced by the bullish attitude of Lugard, fault was placed squarely in the personality of the academic. This inaugurated, from the early 1920 s, the next phase in the experiment in West African colonial anthropology, in which colonial administrators who had undergone training in anthropology were tasked with collecting ethnographic intelligence (Rattray in the Gold Coast; Meek, Matthews and, later, Jeffreys in Nigeria). Kuklick and Stocking follow this orthodoxy, which has purposefully accentuated Thomas's eccentricities and supposed insubordination. In so doing, however, they have failed to take into consideration a number of key factors that a closer scrutiny of the archival record reveals, including: the complexity and contradictions within the colonial administration; the significance of personal prejudices for and against anthropology at all levels of the administrative hierarchy; the tension caused by the colonial governments being obliged to fund what was perceived to be a Colonial Office project; and, indeed, the financial stringencies already present but exacerbated by the outbreak of the First World War. 
Contrary to Kuklick's (1991: 201) assertions, Thomas was not 'sent home' or 'dismissed' from Sierra Leone in 1915 but completed a single tour as was proposed. Nor was 'wartime retrenchment' merely an excuse to get rid of him (Kuklick 1991: 201). Correspondence between the Secretary of State for the Colonies and Governor Merewether concerning Sierra Leone's financial estimates for 1915 makes clear the dire economic situation of the colony, with the Secretary of State insisting that 'every effort should be made to curtail expenditure'. Numerous projects and public works were abandoned, new staff appointments were cancelled, European officials were threatened with direct taxation to make up the shortfall, and, in such circumstances, funding a further anthropological tour was clearly not a priority. ${ }^{51}$

This is not to excuse Thomas of all responsibility. While he made an effort to liaise with district commissioners and submit reports on issues of particular relevance to the administration during his first tour in Southern Nigeria, in subsequent tours he held himself increasingly aloof from the colonial governments that were obliged to pay his salary and whom his research was intended to serve. In the despatch in which he expressed his inclination not to renew Thomas's appointment in Southern Nigeria, Lugard states that he had not received any communication from him concerning the work accomplished during his 1912-13 tour, and that he had had no opportunity of meeting him. It is apparent that Thomas's allegiances remained attached to the Colonial Office itself, from whom he believed he received his mandate. Complaints were received that, on occasion, he would override the concerns of local political officers by invoking the authority of the Secretary of State. ${ }^{52}$ Such an attitude was short-sighted and impolitic to say the least. It is clear that Thomas was resistant to authority, particularly when it was coupled with what he perceived as ignorance or bureaucratic red tape. His arrogance and lack of social acumen meant that he garnered little support among those whom he needed as allies. It is fair to say that, among colonial administrators, his presence was at best tolerated; and when the opportunity arose to dispense with his services, few would come to his defence.

While these personality traits must be taken into consideration, they should not obscure the wider picture, particularly with regard to Thomas's professional competences as an anthropologist and the underlying reasons for the failure of the anthropological experiment. As agreed, in 1910, on his return from his first tour, the Colonial Office approached the RAI to form a committee to examine the results of Thomas's survey and make recommendations regarding whether the work should be continued. The committee was chaired by Risley, erstwhile Director of the Ethnographic Survey of India and then President of the RAI, and, in addition, comprised Read, Haddon, Rivers, Marett and Ray. Two meetings were held in the presence of first Strachey and then Fiddian from the Colonial Office, as well as Thomas himself, who gave 'full explanations of the local conditions and of the methods by which he had proceeded'. The committee provided a detailed report on the materials placed before it, which included anthropometric data, linguistic data and folktales, sociological data, phonographic recordings and photographs. The committee commended Thomas on 'the thoroughness of his enquiries' and the value of his findings 'both for administrative and scientific objects', and expressed its 'emphatic opinion' that the work should continue on a larger scale and 
for a more extended period. ${ }^{53}$ Few anthropologists can have been subjected to such rigorous peer review.

It could be argued, of course, that the RAI committee was predisposed to be supportive of Thomas. The views of political officers on the ground are therefore all the more significant. When asked by Southern Nigeria's Acting Governor, F. S. James, for his opinion of Thomas's work, R. Raikes, the Senior District Commissioner in Onitsha, who claimed to have particular knowledge of 'the peoples in the Benin and Ifon Districts' where Thomas worked, wrote that he had read Thomas's (1910) two-volume report on the Edo-speaking peoples with great interest. He reported that Thomas's work was 'accurate and comprehensive', and would 'prove of great assistance to a political officer placed among Edo speaking tribes'. Raikes considered the second volume, which was concerned with linguistics, to be 'an important work' ${ }^{54}$ There were, however, also contrary views; and, as noted above, doubts were continually expressed by governors as to the value of the anthropological survey considering the expense and the ambiguities regarding who Thomas was answerable to. Thus, at the conclusion of Thomas's second tour in Southern Nigeria, Acting Governor James noted 'that there has been a feeling for some time that the expenditure incurred on the anthropological work carried out by Mr. Northcote Thomas has not been commensurate with the results so far achieved'. Unlike Lugard, however, James was prepared to defer to the expert opinion of the RAI and reluctantly gave the go-ahead for a third tour in the Protectorate, concluding that perhaps 'the time has not yet arrived for a proper value to be placed on the work that has been carried out by Mr. Thomas'. 55

I believe this to be a significant observation that speaks not only to the specific context of Thomas's employment, but also to the then prevailing sense of uncertainty concerning the value of anthropology as both an emergent academic field and an applied social science. As I have argued, Thomas's surveys took place at a time of transition and experimentation in anthropology, when the self-confident assertions of Malinowski's functionalist school had yet to be pronounced, and when paradigms already perceived to be outmoded still lingered (the spectre of anthropometrics, for example). Thomas, too, hovered between the worlds of Victorian academicism and the new professionalism that would emerge in anthropology in the 1920s. He was undoubtedly a man of his time, but also a casualty of that passing experimental moment. Indeed, it is arguably only now, a century later, that the significance of his work is beginning to be more widely appreciated.

It is therefore a sad coda to this tale that, after his fourth tour as government anthropologist in West Africa, Thomas would never again hold a substantial anthropological position. In May 1919 he wrote unofficially to his loyal ally at the Colonial Office, Alexander Fiddian, asking 'if there is any prospect of going out again' or of doing some lecturing in London. ${ }^{56}$ There is no record of a reply, though it seems that Thomas did occasionally lecture in African linguistics as part of the Tropical Africa Services course at the Imperial Institute. To all intents and purposes, it would appear that he effectively retired back to the Border Counties, where he was active for a while in local field clubs and archaeological societies. ${ }^{57} \mathrm{He}$ continued to write occasional academic articles through the 1920 s, and indeed some of his most accomplished anthropological works date from this period. 
This is the accepted version of an article published by Wiley in Journal of the Royal Anthropological Institute Vol. 22 (1), 84-107. Published version available from: https://doi.org/10.1111/1467-9655.12335

Accepted version downloaded from SOAS Research Online: http://eprints.soas.ac.uk/21523/

However, one senses he was aware that his moment had passed, and he retreated into an obscurity from which he is only now, posthumously, beginning to emerge. 
This is the accepted version of an article published by Wiley in Journal of the Royal Anthropological Institute Vol. 22

(1), 84-107. Published version available from: https://doi.org/10.1111/1467-9655.12335

Accepted version downloaded from SOAS Research Online: http://eprints.soas.ac.uk/21523/

\section{REFERENCES}

Afigbo, A.E. 1972. The warrant chiefs. London: Longman.

Alexander, M. 1995. N.W. Thomas (1868-1936): a bibliography. The Nigerian Field 60: 30-3.

Anon. 1909. Anthropology and the empire: deputation to Mr. Asquith. Man 9: 85-7.

Asad, T. (ed.) 1973. Anthropology and the colonial encounter. London: Ithaca Press.

Asad, T. 1991. Afterword. In Colonial situations (ed.) G.W. Stocking. 314-24. Madison: University of Wisconsin Press.

Barton, G. 2002. Empire forestry and the origins of environmentalism. Cambridge: Cambridge University Press.

Beatty, K.J. 1915. Human leopards: an account of the trials of human leopards before the special commission court. London: Hugh Rees.

Blench, R.M. 1995. The work of N.W. Thomas as government anthropologist in Nigeria. The Nigerian Field 60: 20-8.

Cohn, B.S. 1996. Colonialism and its forms of knowledge. Princeton: Princeton University Press.

Dennett, R.E. 1906. At the back of the black man's mind. London: Macmillan.

Dureau, C. 2014. Acknowledging ancestors. In The ethnographic experiment (eds) E. Hviding \& C. Berg, 44-70. New York: Berghahn.

Edwards, E. 2014. Photographic uncertainties: between evidence and reassurance. History and Anthropology 25: 171-88.

Goody, J. 1995. The expansive moment. Cambridge: Cambridge University Press.

Kaeser, M.-A. 2008. Biography as microhistory. In Archives, ancestors, practices (eds) N. Schlanger \& J. Nordbladh, 9-20. New York: Berghahn.

Kuklick, H. 1978. The sins of the fathers: British anthropology and African colonial administration. Research in Sociology of Knowledge, Sciences and Art 1: 93-119.

Kuklick, H. 1991. The savage within. Cambridge: Cambridge University Press.

Kuklick, H. \& R.E. Kohler 1996. Introduction. Osiris 11: 1-14.

Kuper, A. 2015. Anthropology and anthropologists (Fourth edition). London: Routledge.

Lackner, H. 1973. Social anthropology and indirect rule: the colonial administration and anthropology in Eastern Nigeria, 1920-1940. In Anthropology and the colonial encounter (ed.) T. Asad, 123-51. London: Ithaca Press.

Langham, I. 1981. The building of British social anthropology. London: Reidel.

Lewis, H.S. 2014. In defense of anthropology. New Brunswick, N.J.: Transaction.

MacCormack, C.P. 1983. Human leopards and crocodiles: political meanings of categorical anomalies. In The ethnography of cannibalism (eds.) P. Brown \& D. Tuzin, 51-60.

Washington, DC: Society for Psychological Research.

Mack, J. 1990. Emil Torday and the art of the Congo, 1900-1909. London: British Museum.

Malinowski, B. 1929. Practical anthropology Africa 2: 22-38.

Malinowski, B. 1930. The rationalization of anthropology and administration. Africa 3: 405-30.

Malinowski, B. 1967. A diary in the strict sense of the term. London: Routledge \& Kegan Paul.

Mills, D. 2008. Difficult folk? New York: Berghahn.

Pels, P. 2011. Global 'experts' and 'African' minds: Tanganyika anthropology as public and secret service, 1925-61. Journal of the Royal Anthropological Institute (N.S.) 17: 788-810. 
Pels, P. \& O. Salemink 1999. Introduction: locating the colonial subjects of anthropology. In Colonial subjects (eds) P. Pels \& O. Salemink, 1-52. Ann Arbor: University of Michigan Press.

Rivers, W.H.R. 1913. Report on anthropological research outside America. In Reports upon the present condition and future needs of the science of anthropology (eds) W.H.R. Rivers, A.E. Jenks \& S.G. Morley, 5-28. Washington, D.C.: Carnegie Institute.

Rivers, W.H.R. \& R.R. Marett 1907. Preface. In Anthropological essays presented to Edward Burnett Tylor in honour of his 75th birthday, Oct. 21907 (eds) W.H.R. Rivers, R.R. Marett \& N.W. Thomas, n.p. Oxford: Clarendon Press.

Seidman, S. 1983. Beyond presentism and historicism: understanding the history of social science. Sociological Inquiry 53: 79-94.

Stocking, G.W. 1965. On the limits of 'presentism' and 'historicism' in the historiography of the behavioral sciences. Journal of the History of the Behavioral Sciences 1: 211-18.

Stocking, G.W. 1995. After Tylor. Madison: University of Wisconsin Press.

Stoler, A.L. 2009. Along the archival grain. Princeton: Princeton University Press.

Stoler, A.L. \& Cooper, F. 1997. Between metropole and colony: rethinking a research agenda. In Tensions of empire (eds) F. Cooper \& A.L. Stoler, 1-56. Berkeley: University of California Press.

Thomas, N.W. 1896. The École Pratique des hautes Études. Folklore 7: 200-1.

Thomas, N.W. 1898. La survivance du culte totémique des animaux et les rites agraires dans le Pays de Galles. Revue de l'Histoire des Religions 38: 295-347.

Thomas, N.W. 1906 Kinship organisations and group marriage in Australia. Cambridge: Cambridge University Press.

Thomas, N.W. 1908. The market in African law and custom. Journal of the Society of Comparative Legislation 19: 90-106.

Thomas, N.W. 1910. Anthropological report on the Edo-speaking peoples of Nigeria, 2 vols. London: Harrison \& Sons.

Thomas, N.W. 1913-14. Anthropological report on the Ibo-speaking peoples of Nigeria, 6 vols. London: Harrison \& Sons.

Thomas, N.W. 1916. Anthropological report on Sierra Leone, 3 vols. London: Harrison \& Sons. Thomas, N.W. 1917. Secret societies in West Africa. Man 17: 173-4.

Tilley, H. (ed.) 2007. Ordering Africa. Manchester: Manchester University Press.

Tylor, E.B. 1871. Primitive culture, vol. 1. London: John Murray.

Urry, J. 1993. Before social anthropology. Abingdon, Oxon: Routledge. 
van der Bersselaar, D. 1998. In search of Igbo identity. Leiden: University of Leiden. van der Bersselaar, D. 2004. Establishing the facts: P.A. Talbot and the 1921 census of Nigeria. History in Africa: 31: 69-102.

Wyse, A.J.G. 1990. H.C. Bankole-Bright and politics in colonial Sierra Leone, 1919-1958. Cambridge: Cambridge University Press. anthropological mission to Sierra Leone, 1914-15' (RF-2013-234), for which I am extremely grateful. I should also like to thank Mark Alexander, Mandy Banton, Roger Blench, Jocelyne Dudding, James Fairhead, Alfred Forna, Rachel Hand, Norman Home, Ohioma Pogoson, David Pratten, Nicholas Thomas and Sarah Walpole for their assistance and encouragement.

${ }^{1}$ See Kaeser (2008) for a recent discussion of historicism, microhistory and scientific biography in the history of archaeology.

2 The National Archives (TNA) CO520/127, Gov.31844/13, Lugard to Harcourt, 11.9.13.

${ }^{3}$ TNA CO583/176/9, 1003/30, Fiddian memorandum, 16.12.30; Ibid., Flood to Fiddian, 19.12.30.

${ }^{4}$ Despatch from the Secretary of State for the Colonies to the officer administering the government of Nigeria regarding the report of the Commission of Inquiry into the disturbances at Aba and other places in south-eastern Nigeria in November and December 1929, p.4.

${ }^{5}$ Ibid., p.6. Lord Passfield - Sidney Webb - was, of course, a well-known socialist, early member of the Fabian Society and a founder of the London School of Economics and Political Sciences.

${ }^{6}$ Ibid.

${ }^{7}$ In unpublished jottings on Lugard's Dual Mandate written in the mid-1920s, Malinowski notes the potential value of anthropology in the context of indirect rule. Much may be read into the exclamation mark that he sets against Thomas's name in answer to his rhetorical question, 'What has been done towards it?'. LSE, Malinowski papers 10/18.

${ }^{8}$ TNA CO583/176/9, Flood to Fiddian, 19.12.30.

${ }^{9}$ TNA CO520/127, Gov.31844/13, Fiddian minute, 22.9.13. The clerks of the West African Department were not well disposed toward Lugard.

10 The Anthropological Institute was given permission to use the term 'Royal' in 1907.

${ }^{11}$ Minutes of meeting, 16 January 1907, Folklore 18: 4-5. Seligmann anglicized his surname to Seligman in 1914.

12 TNA CO96/480, T.21881/08, Tylor to Antrobus, 15.6.08.

13 TNA CO87/174, R.34648/05, Russell to Elgin, 27.9.05.

${ }^{14}$ Ibid., proof of printed despatch sent to governors in West Africa, 20.3.06.

15 Ibid.

${ }^{16}$ The questionnaire to which Dennett refers is likely to have been the Questionnaire Ethnographique, published by the Belgian government in 1905 for use in the Congo. Thomas had been involved in drafting it (Mack 1990: 29).

17 TNA CO520/41, E.24646/06, Dennett to Egerton, 3.7.06.

${ }^{18}$ Ibid., Antrobus to Egerton, 27.7.06.

${ }^{19}$ TNA CO446/72, H.C.9442/08, Wallace to Elgin, 8.2.08. On the relationship between 'custom', 'law' and 'customary law' in British colonial administration see Asad (1991: 321-22).

${ }^{20}$ TNA CO96/480, T.21881/08, Tylor to Antrobus, 15.6.08.

${ }^{21}$ Ibid., Antrobus to Thomas, 13.7.08.

${ }^{22}$ TNA CO96/480, T.30351/08, Thomas to Antrobus, 19.8.08.

${ }^{23}$ Ibid., Fiddian minute, 21.8.08.

${ }^{24}$ Ibid.

25 TNA CO96/480, R.30181/08, Frazer to Antrobus, 21.8.08.

${ }^{26}$ RAI Archives \& Manuscripts MS 199 to 203.

27 TNA CO96/480, T.32070/08, Crewe to Egerton, 3.9.08.

${ }^{28}$ TNA CO520/65, Gov.33046/08, Egerton to Crewe, 9.9.08.

${ }^{29}$ Ibid., Fiddian minute, 24.9.08. Thomas and Thompson appear to have shared an address in Buntingford, Hampshire for a number of months in 1908 .

${ }^{30}$ Ibid., Antrobus to Thomas, 28.9.08 [emphasis added].

${ }^{31}$ Ibid.

32 TNA CO520/113, Gov.3629/12, Estimates 1912, 15.1.12.

33 TNA CO96/538, Gov.39112/12, Strachey minute, 13.11.13.
} 


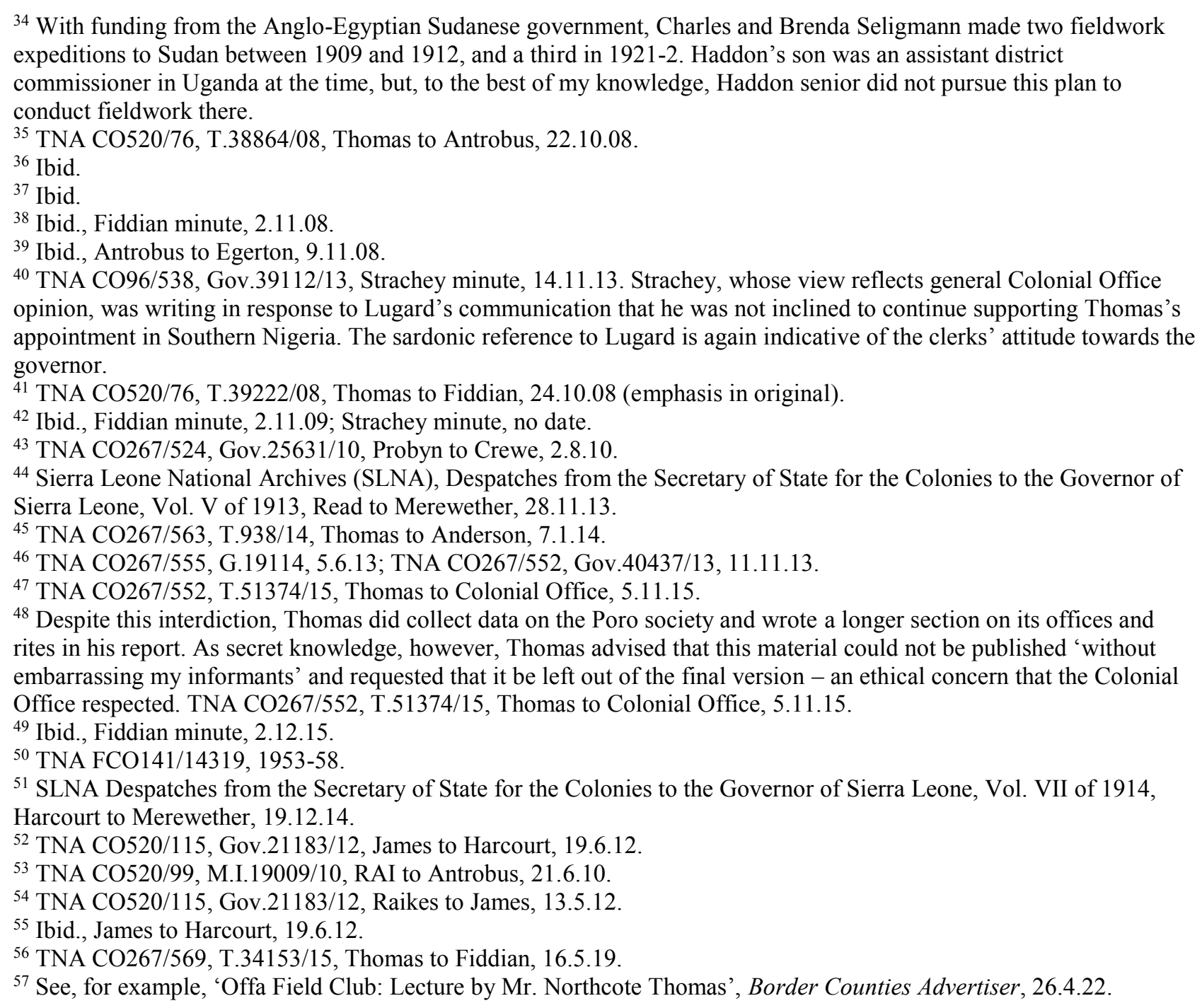

